\title{
Failure of Research-Based Learning Implementation in Basic Education
}

\author{
Wattana Rattanaprom ${ }^{1}$ \\ ${ }^{1}$ Department of Curriculum and Instruction, Faculty of Education, Suratthani Rajabhat University, Thailand \\ Correspondence: Wattana Rattanaprom, Department of Curriculum and Instruction, Faculty of Education, \\ Suratthani Rajabhat University, Thailand.
}

Received: September 9, 2018

doi:10.5539/ies.v12n4p19

\author{
Accepted: December 4, 2018 Online Published: March 10, 2019 \\ URL: https://doi.org/10.5539/ies.v12n4p19
}

\begin{abstract}
This study focuses on identifying the barriers and obstruction factors of Research-Based Learning (RBL) which was implemented in the schools under "Pohpanpanya" Youth Researcher Development Research Program. RBL consists of three domains: Contemplative Education (CE), System Thinking (ST) and Professional Learning Community (PLC). Those are processes of coaching and mentoring master teachers (MTs) to coach and facilitate their students for RBL. This research program was implemented in ten volunteering schools which were substantially improving the learning outcomes of their students. However, being a relatively new mode of teaching the management of the teaching and learning processes remains a challenge especially with the four main barriers; 1) teacher mindset 2) teaching methodology 3) curriculum design, and 4) academic leadership.
\end{abstract}

Keywords: research-based learning, contemplative education, system thinking, professional learning community

\section{Introduction}

The Research-Based Learning (RBL) pedagogy was developed under Pohpunpanya Project (Young Researcher Development) research program (Prasertsan, 2013). It was conducted with ten volunteering secondary schools in Surat Thani ( 7 schools) and Nakhon Si Thammarat (3 schools) Province, Thailand. It has been implemented in 2013 to present. It was focused on systematic thinking skill development of secondary school students who were coached by their master teacher. Each school selected a class of 25-64 Mathayomsuksa 2 or Grade 8 students. The 50 master teachers and 358 students joined this research program. The RBL activities were conducted by the master teachers. They promoted their students to produce ten research-based projects beneath a single local theme related to the context of each school.

These RBL models are in fact quite different in terms of the nature of knowledge formation and the degrees of self-directed learning, which theoretically, should result in different types of learning outcomes.

This research program produces positive movements in active learning and self-directed learning in every school, which joined in this research program. It produces transformation change in both master teachers and their students. The master teachers changed their teaching to facilitating and coaching behaviors. However, there were 4 volunteering schools which have resigned from this research program between 2014 to the present. The aim of this study is to find out what obstacles are barriers of RBL implementation.

What is Research-Based Learning?

The RBL are systematic learning activities of students for constructing their own understanding and knowledge, through research-based projects and reflection on those learning experiences. It let students think freely and synthesize the knowledge from empirical data or information from research-based project and let them present their knowledge to the public via various channels, i.e., writing, presentations and exhibitions.

RBL consist of three domains: 1) Contemplative Education (CE), 2) System Thinking (ST) and 3) Professional Learning Community (PLC).

$\mathrm{CE}$ is the fundament of ST and PLC focused on trust activity, self-analysis, deep listening, dialogue and meditation. Those learning activities provide a safe atmosphere between master teachers and students leading to freely, deeply and seriously thinking.

ST is thinking skills to identify not only reasons but also the relationship of "cause" and "effect" in a 
research-based project, which is completed by the students. The students drew cause-effect mind mapping. The students will link between cause and effect with a solid line one-way arrow (------>), if cause and effect are in a positive relation. On the other hand, the students will link them with a dash line one-way arrow $(--->)$, if they are in a negative relation.

PLC is the process of learning activities for improvement of master teachers to teach their students by before teaching review (BTR), teaching record (TR) and after teaching review (ATR) using coaching and mentoring skills.

\section{Methodology}

This study was designed in accordance with a qualitative research approach. Focus group discussion was used in different groups of participants; active schools vs. resigned schools, and principal vs. master teachers' view. There were four separate focus group discussions according to the groups of participants.

\subsection{Participants}

The participants of the study were principals and master teachers who were then undergoing a workshop of RBL modules and later were going to teach with the RBL methodology. Purposive sampling was utilized to identify participants. There were 36 participants in the study: 12 principals and 24 master teachers from active schools in the research program.

Since this research involves master teachers as respondents, their names, and other personal information were kept anonymously for ethical considerations. They were made aware of the purpose of the research, that their participation in the study was voluntary, and that all the information would be treated with utmost confidentiality.

\subsection{Data Collection Process}

The aim of the research was to investigate if principal perspectives and master teachers experiences were "the key failure factors of RBL implementation in basic education". Research data was collected through 2 different focus group discussions, i.e. 1) Principals, 2) Master teachers. The following steps were realized during the focus group discussion.

The questions for focus group discussion were prepared with specific attention on the aim of this research, consisting of 2 main questions. Those are "what are the key failure factors for the RBL implementation in basic education?" and "Which are the key failure factors occurring in your school?" In the following step, every participant was given 10 minutes for writing down their own perspectives or experiences on an A4 blank paper. After that, each participant shared their perspectives or experiences to the group and discussed them. The focus group discussion meetings were taken place in a meeting room at Suratthani Rajabhat University and a tape recorder was used to record the participants' responses during the focus group discussion. In total, two focus group discussions were planned and conducted with different groups of participants, as following: 1) a group of 12 principals 2) a group of 24 master teachers from all schools in the RBL research program.

\subsection{Data Analysis}

The data collected from the discussions done with the participants was analyzed with content analysis which is among the qualitative data analysis according to the Colizzi (1978) method.

Thematic analysis was used to identify the conceptual understanding, factors hindering application of barriers and obstacles for implementing RBL in real situations in each school.

Firstly, the writing statement and opinion from each participant which included each interview done with the participants were transferred to Microsoft Word. Secondly, each data obtained through the discussion was coded, respectively. The coding process was completed by choosing the appropriate expression on the Word page and recording the appropriate code as statement code. Thirdly, thematization process followed the coding process; the obtained codes were grouped under the appropriate themes. Finally, themes were created by checking the similarities of these sub-themes.

\section{Results}

It is evident that the researcher can implement RBL research programs to positively impact student achievements (Rattanaprom, 2017; Rattanaprom, Songsawat, \& Phongsuwan, 2017). This does not seem to be true among all schools due to multiple barriers experienced by principles and master teacher. This study collected data from two focus group discussions of principals and master teacher separately as following. 


\subsection{Perspective of Principals}

The principals paid attention on academic support of RBL implementation. All of them strongly agreed with the lack of administrative and academic support were a major barrier of implementation of RBL. Especially, the master teachers are lack of administrative support and academic support from the administrators. The participants mentioned about the lack of understanding in RBL methodology, supporting teams, and master teachers in their schools. It was the lack of communication in their school due to resistance from other teachers in their school.

Furthermore, the principals were not allowed to adjust their school curriculum to provide time for RBL teaching. They implemented RBL as student development activities. This means a teaching hours overload for their master teachers. The principals discussed about the implementation of RBL without full afford and were not open minded for changing the teaching methods of the master teachers. They discussed about that some of the master teachers did not teach RBL, they would focus on the summary or presentation, or the time being supervised or evaluated. The RBL implementation was taken away from supervision.

\subsection{Perspective of Master Teachers}

The master teachers were very important in RBL implementation. The RBL research program staff conducted workshops for preparing those teachers, for example; a contemplative education workshop, a system thinking workshop and a professional learning community workshop, to develop RBL skills.

All master teachers paid attention on understanding of the RBL methodology. They felt unfamiliar with RBL teaching and they still adhered to the traditional teaching style that was taught. They worried about their research skill, which they had to transfer to their students. They thought that if they were not confident towards preparing their students using contemplative education and system thinking- the core skills of RBL, they would fail. Some of them showed that they didn't want to change anything because of their work load.

The master teachers mentioned about their many duties in everyday life including their students, which was the main barrier for RBL implementation. In addition, their students usually are attending class for 6-7 hour per day according to school curriculum. The master teachers were assigned to teach RBL in the student development activity hours, during extracurricular school club. That was an overloading task for both of the master teachers and the students.

The master teachers discussed about the lack of learning inspiration of their students. Their students were familiarized with a traditional teaching style-teacher-centered approach.

The classroom involvement resulted with an immediately response to unplan extra-curricular activities from the Educational Administrative Office.

In addition, the master teachers lack resources for enrichment their instruction.

\section{Discussions}

This study was grounded from the research 4 theme, consisting of 1) teacher mindset 2) teaching methodology 3) curriculum design, and 4) academic leadership as following.

\subsection{Teacher Mindset}

Mindset has emerged as a term used to describe the belief that either academic ability can be cultivated in all students or academic ability cannot be changed (Dweck, 2006). NCTM (2014, p. 64) reported research showing that "believing in, and acting on, growth mindsets versus fixed mindsets, that can make an enormous difference in what students accomplish". The results show that the master teachers from performing schools have a more positive perspective than underperforming schools. The master teachers from performing schools worked together to design lesson plans in a warm atmosphere and changed the teaching styles facilitated through funny learning activities. The master teachers from one underperforming school usually projected their performance on the students' ability. The principal descripted that they confronted the resistance from the other teachers. They couldn't change the other teachers' mindset.

\subsection{Teaching Methodology}

All three components of RBL; contemplative education, system thinking, and professional learning community, those are difficult to practice. Both of principals group and master teachers group reflected this issue. Especially, the system thinking is a higher order thinking skill. The characteristics of master teachers with a higher order thinking skill are open-mindedness for risk-taking, curiosity, keen on fact discovery, planning and indicating the most suitable method, have a system thinking process, think carefully, use evidence to think rationally and 
frequent self-monitoring (Tishman et al., 1993). All these skills should be transferred to their students, which isn't easy if the master has a lack of those competencies. The PLC is a major tool of RBL for teaching improvement, in order to improve educational practices for increasing students' achievement through enhanced communication and collaboration among teachers. But nobody concerned this issue.

\subsection{Curriculum Design}

The results show that all schools can't integrate RBL into the school curriculum as well. It was conducted during extracurricular activities. That means an overload of tasks for both of master teachers and their students. In traditional practices, only one teacher is responsible for one subject independently, but the RBL needs a team of teachers to work together for conducting learning sessions. The performing schools tried to merge Pohpunpanya Club into an independent study course or redesigned the school curriculum by replacing old subjects with Pohpunpanya subjects.

\subsection{Academic leadership}

The results show that both of principals and master teachers are confronted with academic leadership. The principal can't manage all teachers to launch RBL. In fact, principals as leaders who are in a position to influence teachers must have RBL skills. Strong leadership from the principal is essential when maintaining a trusting climate and culture supporting effective teaching and student achievement (Louis, Leithwood, Whalstrom, \& Anderson, 2010). At the same time, the master teachers aren't strong academic leaders. They usually have the same teaching style that focuses on subject matter delivery. In contrast, the RBL teaches students by facilitating and coaching the students how to learn and contemplate about the surrounding environment in daily life.

\section{References}

Baxter, P., \& Jack, S. (2008). Qualitative Case Study Methodology: Study Design and Implementation for Novice Researchers. The Qualitative Report, 13(4), 544-559. Retrieved from https://nsuworks.nova.edu/tqr/vol13/iss4/2

Colaizzi P. (1978). Psychological research as the Phenomenologist views it. In Existential - Phenomenological Alternatives for Psychology (Valle, R. \& King, M., Eds, pp. 48-71). London: Oxford University Press.

Dweck, C. S. (2006). Mindset: The new psychology of success. New York, NY: Random House.

Louis, K. S., Leithwood, K., Wahlstrom, K., \& Anderson, S. (2010). Investigating the links to improved student learning: Final report. Minneapolis: University of Minnesota Center for Applied Research and Educational Improvement.

Louis, K. S., Leithwood, K., Whalstrom, K. L., \& Anderson, S. E. (2010). Learning from leadership: Investigating the links to improved student learning. New York: The Wallace Foundation.

National Council of Teachers of Mathematics. (2014). Principles to actions: Ensuring mathematical success for all. Reston, VA: Author.

Rattanaprom, W. (2017). Research-Based Learning: The Magic Tool for Improving Teaching and Learning Outcome: A case study of Tha-Utae Pittaya School. In Proceeding of the World Congress on Education, 1(1) 52-56, July 17-19, 2017, Dublin, Ireland: Infonomics Society.

Rattanaprom, W., Songsawat, K., \& Phongsuwan, M. (2017). Research-Based Learning in Moderate Class, More Knowledge Campaign: A Case Study of Ban Klong Sa School, Surat Thani, Thailand. In Proceedings of the International Conference on Education and Learning, 1(1), 262-267, 16-18 August 2017. Tokyo: Global Academic-Industrial Cooperation Society.

Tishman, S., Jay, E., \& Perkins, D. N. (1993). Teaching Thinking Dispositions: From transmission to enculturation. Theory into Practice, 32(3), 147-153. https://doi.org/10.1080/00405849309543590

Waters, T., Marzano, R.J., \& McNulty, B. (2003). Balanced leadership: What 30 years of research tells us about the effect of leadership on pupil achievement (A working paper). Aurora, CO: Midcontinent Research for Education and Learning. 


\section{Copyrights}

Copyright for this article is retained by the author(s), with first publication rights granted to the journal.

This is an open-access article distributed under the terms and conditions of the Creative Commons Attribution license (http://creativecommons.org/licenses/by/4.0/). 